DOI: https://doi.org/10.47405/mjssh.v6i10.1099

\begin{tabular}{|c|c|}
\hline 4 & Malaysian Journal of Social Sciences and Humanities (MJSSH) \\
\hline $\begin{array}{l}\text { Malaysian Juoural of } \\
\text { Social ccciecces and }\end{array}$ & Volume 6, Issue 10, October 2021 \\
\hline (MJ-sSH) & e-ISSN : 2504-8562 \\
\hline & $\begin{array}{l}\text { Journal home page: } \\
\text { www.msocialsciences.com }\end{array}$ \\
\hline
\end{tabular}

\title{
Perilaku Membeli dan Pilihan Makanan dalam kalangan Generasi Milenial: Suatu Sorotan Awal
}

\author{
Fahmi Ilman Fahrudin'1 \\ 1Prodi Teknologi Pangan, Fakultas Sains and Teknologi, Universitas Muhammadiyah Bandung, Indonesia
}

Correspondence: Fahmi Ilman Fahrudin (fahmilmanf@umbandung.ac.id)

\begin{abstract}
Abstrak
Artikel ini merupakan hasil analisis dan pemikiran berdasarkan literatur mengenai pilihan makanan dan perilaku membeli dalam kalangan generasi milenial. Generasi milenial dengan penguasaan teknologi informatika dan media sosial kini memegang kendali trend makanan di seluruh dunia. Gaya hidup yang serba cepat dan praktis mempengaruhi perilaku mereka dalam hal membeli dan selanjutnya berpengaruh terhadap pilihan makanan. Pilihan makanan generasi milenial kadang kala tidak lagi mempertimbangkan apakah makanan tersebut sihat atau tidak. Hal ini kerana pilihan makanan lebih disebabkan oleh gaya hidup, sub budaya popular dan pengaruh media sosial. Diperlukan suatu tindakan yang komprehensif untuk memperbaiki literasi generasi milenial mengenai pengurusan kewangan, perilaku membeli, pilihan makanan dan makanan yang sihat.
\end{abstract}

Kata kunci: generasi milenial, pilihan makanan, perilaku membeli, makanan sihat

\section{Buying Behavior and Food Choices Among Millennials: A Preliminary Review}

\begin{abstract}
This article is the result of analysis and thought based on various published research on the millennial generation's food preferences and purchasing behaviour. The millennial generation, which has mastered information technology and social media, presently controls global food trends. Their fastpaced and practical lifestyle influences their purchasing behaviour, which in turn affects their food choices. Millennials' food choices frequently disregard whether or not the diet is healthy. These food choices are influence by lifestyle, subculture, and social media influence. A comprehensive action plan is required to increase the millennial generation's financial literacy, purchasing behaviour, food choices, and healthy eating habits.
\end{abstract}

Keywords: millennials, food choices, buying behaviour, healthy food

\section{Pengenalan}

Kemajuan teknologi telah mempengaruhi berbagai aspek kehidupan manusia termasuk dalam soal pilihan makanan. Kemajuan teknologi kini sangat memudahkan orang dalam memilih makanan. Kehadiran Gojek dengan aplikasi Go Food, Grab dengan Grab Food dan kini Shopee Food semakin 
mempermudah orang dalam memilih makanan. Pilihan makanan ditentukan oleh banyak faktor baik faktor individu, faktor sosial dan lingkungan. Karya Lewin $(1943,1951)$ merupakan kerangka rujukan (frame of reference) pertama kali menjelaskan faktor yang mempengaruhi pilihan makanan di antaranya rasa, kesihatan, status sosial, dan biaya. Beberapa penelitian berikutnya berkaitan pilihan makanan ada pula yang memfokuskan pada kognitif dan faktor motivasi yang terlibat dalam memilih makanan (Bell et.al, 1981; Michela \& Contento, 1986). Manusia khususnya remaja dan generasi milenial dihadapkan dengan beberapa pilihan makanan setiap hari dan membuat keputusan tentang makanan apa yang akan dikonsumsi berdasarkan beberapa pilihan kriteria. Keperluan akan makanan adalah keperluan dasar, fisiologi dengan tujuan yang jelas dan sederhana dan tampaknya solusi lurus tentang bagaimana menjadi puas (Mela, 1999). Nampak sederhana kelihatannya, namun pilihan makanan sangat beragam dan tidak harus lurus ke depan. Hal ini menandakan bahawa setiap orang memiliki perbezaan dari segi pemilihan makanan. Selain itu, pilihan yang dibuat orang mengenai makanan yang dipilih akan menentukan nutrisi yang masuk ke dalam tubuh dan mempengaruhi sistem produksi pangan melalui permintaan dan perilaku konsumen. Pilihan makanan pula dalam jangka panjang pada akhirnya meletakkan dasar bagi kebiasaan (habit) dan perilaku makan terutama bagaimana orang mempertimbangkan dan memilih makanan. Hakikatnya, proses memilih makanan menggabungkan tidak hanya keputusan berdasarkan refleksi sadar, tetapi juga reaksi secara automatik, kebiasaan dan alam bawah sadar mereka. Artikel ini secara khusus ingin membahaskan budaya dan gaya hidup generasi milenial dan kaitannya dengan pilihan makanan serta makanan yang sehat bagi mereka.

\section{Sorotan Literatur}

\section{Pengertian Generasi Milenial}

Milenial yang juga dikenal sebagai generasi Y merupakan kelompok pengguna penting bagi industri pelancongan dan perhotelan. Sejak adanya peningkatan penelitian mengenai "Milenial" (Generasi Y), yang lahir antara tahun 1980 dan 2000, baik akademik mahupun profesional mulai fokus pada perilaku generasi ini (Lancaster \& Stillman, 2003). Dalam mempertimbangkan kajian mengenai generasi, penelitian membuktikan bahawa generasi yang berbeza memiliki nilai, keyakinan, dan sikap yang berbeza yang menghasilkan perilaku yang berbeza (Inglehart \& Carballo, 1997). Artinya, sangat penting untuk memahami perilaku milenial kerana mereka mewakili pengguna masa depan. Milenial, yang juga disebut sebagai generasi Y, terdiri dari orang-orang yang berusia antara 19 dan 37 tahun. Oleh kerana itu, generasi ini adalah kelompok pengguna termuda kedua pada tahap kehidupan yang berbeza ini. Sementara beberapa dari mereka masih belajar di universiti dan tinggal bersama keluarga mereka, yang lain hidup sendiri atau sudah menikah. Oleh kerana itu, berada pada tahapan kehidupan yang berbeza mempengaruhi nilai, gaya hidup, keperluan, dan keinginan generasi milenial. Hal ini juga mempengaruhi aktiviti hiburan mereka, bagaimana mereka memandang politik dan peristiwa terkini, sikap mereka terhadap memasak, apa yang mereka makan serta bagaimana mereka berbelanja barang keperluan sehari-hari. Selain itu, keragaman budaya mereka juga mempengaruhi minat untuk pelbagai jenis makanan dan permintaan untuk masakan etnik yang berbeza. Maka, dapat disimpulkan bahawa generasi milenial merupakan generasi yang memiliki tuntutan khusus terhadap makanan dan minuman serta yang mencari untuk memenuhi tuntutan tersebut. Kesimpulannya, tujuan dari penelitian ini adalah untuk memahami faktor-faktor apa saja yang mempengaruhi pilihan makanan milenial, kepentingan relatif mereka, dan bagaimana mereka berbeza berdasarkan faktor demografi yang berbeza.

\section{Gaya Hidup Generasi Milenial}

Milenial yang juga dikenal sebagai generasi $\mathrm{Y}$ telah terintegrasi dengan teknologi di setiap tahap kehidup mereka. Golongan milenial akan mencari di Google, Facebook, Pinterest, dan YouTube untuk resepsi dan makanan. Mereka juga menggunakan media sosial untuk berkongsi pandangan dan pengalaman mereka dengan teman, keluarga, dan orang lain untuk mendiskusikan pendapat mereka. Melalui perkongsian pandangan ini atau mengikuti orang lain, milenial sama-sama mengembangkan Dilistan Shipman. Generasi Y biasanya mengikuti orang-orang yang berkongsi pendapat atau orang- 
orang yang merupakan bagian dari kelompok yang mereka ingin menjadi anggota. Akibatnya, aktiviti ini tidak hanya membentuk nilai dan keyakinan mereka, tetapi juga mempengaruhi pilihan makanan dan keputusan pembelian mereka (Wohl, 2016). Alasan mengapa milenial, generasi Y, suka berbagi semua jenis pengalaman makanan di media sosial adalah kerana mereka terbiasa menyatakan individualistik mereka bahkan jika rangkaian sosial terdiri dari pendapat kolektif (Leslie, 2016). Selanjutnya, mereka juga memesan berbagai jenis makanan dari restoran yang sama untuk mempersonalisasikan dan mengindividualisasikan pengalaman media sosial mereka. Selain itu, mereka terkadang mengubah pilihan piring makanannya dengan menggunakan cangkir sebagai pengganti piring atau sebaliknya (Watson, 2016). Generasi ini selalu mencari hal-hal baru dan mereka juga ingin mempersonalisasi makanan dengan presentasi yang berbeza. Penelitian sebelumnya telah menunjukkan bahawa makan tidak hanya bererti kenyang, tetapi merupakan cara untuk mengekspresikan diri sekaligus kesempatan untuk memperoleh pengalaman baru. Apalagi bagi generasi Y, makanan menjadi alasan untuk bersosialisasi dan menyatukan masyarakat pada era yang serba digital. Generasi ini biasanya online untuk memeriksa akaun mereka dan orang-orang yang mereka ikuti. Dengan cara ini, mereka dapat membagikan gambar atau menggunakan gambar serupa yang mereka lihat di akaun orang yang mereka ikuti. Sementara generasi ini sukses menggunakan media sosial, mereka juga berkongsi video dan setiap momen mereka hidup dengan pengikut mereka. Mereka menggunakan media sosial untuk tujuan pemasaran dengan menghasilkan penjualan dan pemasaran makanan yang mereka masak melalui Instagram. Makanan tersebut biasanya mewakili makanan trendi dan beberapa milenial melangkah lebih jauh dengan membuat tren mereka sendiri dalam video di saluran YouTube. Generasi ini juga membantu menentukan perilaku pembelian dan pilihan makanan untuk masa depan. Dalam konteks ini, generasi Y dapat dianggap sebagai penentu tren baru. Selain itu, mereka berbeza dari generasi lain karena mereka suka menemukan hidangan dan selera baru dan lebih suka pengembaraan yang sesuatu yang berbeza.

Generasi ini juga membantu menentukan perilaku pembelian dan pilihan makanan untuk masa depan. Dalam konteks ini, generasi Y dapat dianggap sebagai penentu tren baru. Selain semua diskusi tersebut, penelitian juga menyebutkan bahawa kaum milenial memperhatikan masalah etika dalam pilihan makanan mereka. Artinya, mereka lebih cenderung membeli makanan yang kemasannya ramah lingkungan (Capon, 2012). Oleh karena itu, kemasan suatu produk juga menjadi parameter keputusan pembelian mereka. Karena kemasan merupakan titik kontak pertama dengan suatu barang, kemasan yang baik merupakan cara untuk menarik pelanggan (Gillian \& Wilson, 2012). Sejalan dengan temuan ini, rasa hormat generasi Y terhadap lingkungan juga menghasilkan kepedulian mereka terhadap kemasan. Untuk itulah perusahaan perlu menggunakan bahan kemasan yang ramah lingkungan dan memperhatikan daur ulang bahan tersebut.

Rajah 1: Pertumbuhan pasar makanan di Amerika Utara dalam USD tahun 2014-2025

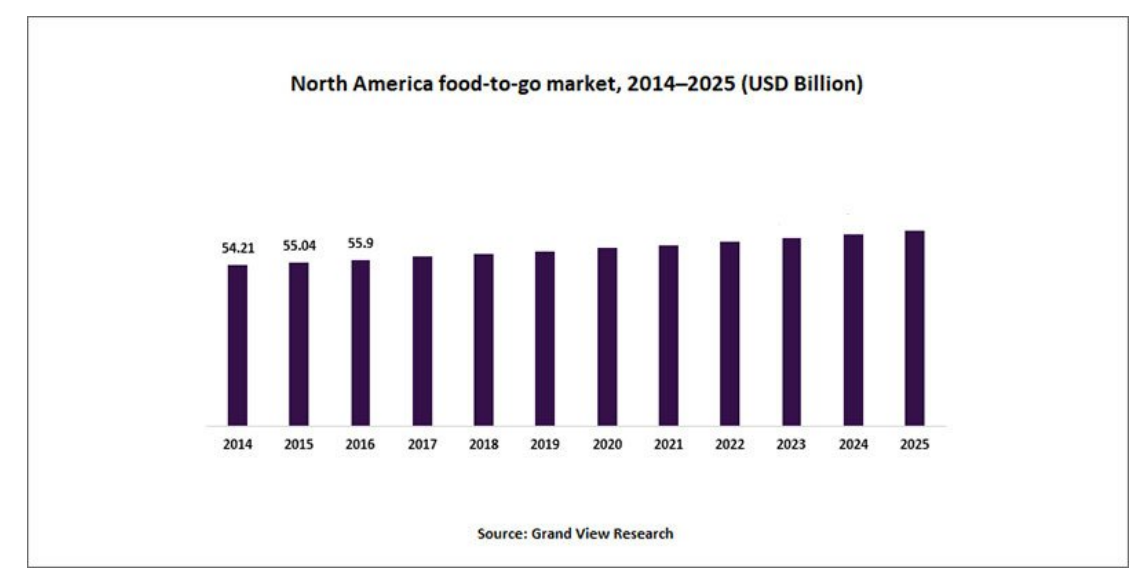

Di bidang pemasaran, populasi milenium dianggap sebagai kekuatan untuk diandalkan, terutama di negara-negara maju seperti Amerika Syarikat dan Kanada. Menurut Biro Bancian Amerika Syarikat, 83,1 juta warga di negara itu diklasifikasikan di bawah kategori milenial menurut perkiraan pada tahun 2015. Jumlah ini mencerminkan seperempat dari total populasi negara itu. Sejalan dengan itu, produk makanan inovatif dengan kemasan yang menarik pada prinsipnya menyasar segmen penduduk di 
negeri ini. Tren utama yang telah mengubah landskap makanan di tingkat global adalah mengutamakan makanan yang nyaman. Dalam hal ini, konsep konsumsi makanan siap saji atau makanan siap saji telah mendapatkan populariti besar di industri makanan. Perkembangan ini digarisbawahi dengan pergeseran pola konsumsi pangan, terutama di bidang pangan atau jajanan rakyat dan pertanian organik. Kebiasaan membeli kaum milenial terlihat sangat berbeza dibandingkan dengan generasi baby boomer.

Jadual 1: Lanskap industri makanan dunia

\begin{tabular}{ll}
\hline Produk Makanan & Jenis \\
\hline Indian flavours & Naan, chutney, and curry dishes \\
Fermented flavours & Kimchi, pickled vegetables, and kombucha \\
Sweet \& savoury mashups & Jalapeno breakfast bars or bacon donuts \\
Exotic peppers & Jalapeno, habanero, ancho, serrano, and chipotle \\
\hline
\end{tabular}

\section{Perilaku Membeli dan Tren Makanan Kaum Milenial}

Sementara baby boomer cenderung membeli produk makanan di supermarket konvensional, perilaku pembelian milenial ditandai dengan banyaknya penggunaan platform belanja online. Pengamatan utama dalam perilaku pembelian generasi milenial adalah pilihan makanan khusus yang mencakup produk makanan alami, organik, dan etnik, karena ketersediaan dan kemampuan mereka untuk membelanjakan lebih banyak untuk produk makanan yang mereka hargai (Honnappa, 2019). Selain produk makanan, industri makanan juga mengalami perubahan dalam berbagai alat komunikasi, khususnya di bidang pemasaran dan penjualan. Produsen produk makanan telah meningkatkan tugas untuk memenuhi beragam tuntutan milenium. Misalnya, pada tahun 2018, MTR Foods Pvt Ltd., sebuah perusahaan produk makanan India, bekerja untuk menciptakan resep yang ramah Amazon Alexa. Hasil dari langkah strategis tersebut adalah untuk memanfaatkan keperluan berdasarkan pengalaman yang dipersonalisasi di kalangan konsumen, terutama kaum milenial, dalam hal ini konsumsi makanan. Tren makanan di kalangan milenial diperkirakan akan semakin berkembang seiring dengan tren yang muncul di industri makanan siap saji. Honnappa (2019) mencatat tren nyata yang mencengkeram industri makanan yang berkaitan dengan konsumsi makanan di kalangan milenial selama beberapa tahun terakhir sebagai berikut:

\section{Eksperimen rasa: Tren yang menentang konsep loyalitas merek}

Dalam upaya untuk mencuba berbagai macam masakan dari seluruh dunia, kombinasi dari berbagai hidangan dianggap menarik bagi para pemakan petualang. Beberapa tren mencekam lainnya dalam hal ini adalah indikasi peningkatan konsumsi makanan fusion termasuk donat, dan sushi burrito untuk beberapa nama. Media sosial telah menawarkan dorongan yang diperlukan untuk produk makanan tersebut untuk mendapatkan popularitas. Beberapa produk lain yang terus menjadi penting di kalangan milenium di seluruh dunia termasuk es krim gulung, poke, dan makanan penutup eksotis.

\section{Sup super premium: Memicu respons nostalgia}

Obsesi kaum milenial terhadap kebiasaan makanan sihat ditambah dengan keperluan akan gaya hidup sehat mengharuskan produk makanan yang lebih sihat, termasuk sup, sebagai pilihan popular. Dalam hal ini, sup super premium telah muncul sebagai favorit milenial di seluruh dunia. Sementara sup super premium mencakup berbagai bahan yang sihat atau bersih, sup ini juga ekonomis dan memberikan pilihan makanan lengkap yang tersedia untuk dikonsumsi. Produk-produk makanan ini juga menawarkan respons emosional yang diperlukan bagi kaum milenial, serupa dengan pengalaman yang dialami anak-anak saat menikmati semangkuk sup ayam pada hari tertentu. Meningkatnya konsumsi sup super premium membuat generasi lain, termasuk baby boomer, mengikuti jejak mereka. Intinya, manfaat kesihatan yang terkait dengan sup super premium diharapkan dapat mempertahankan pengambilannya dalam kalangan milenial selama dekad berikutnya. 


\section{Flexitarianisme: Menempatkan konsumsi daging di bawah pengawasan}

Flexitarianisme, juga disebut sebagai 'vegetarisme kasual' menyoroti asupan makanan yang lebih sehat, terutama bahan makanan nabati. Sementara diet flexitarian sebagian besar mencakup makanan yang mengandung protein seperti kacang-kacangan, lentil, kacang polong, biji-bijian dan kacangkacangan, itu tidak menghilangkan asupan daging sepenuhnya, seperti yang disukai oleh pola fikir milenial.

\section{Personalisasi: Mewujudkan pilihan yang disesuaikan}

Generasi milenial telah mengembangkan hasrat mereka untuk pilihan makanan yang dapat disesuaikan di seluruh dunia. Telah diamati oleh gerai layanan makanan dan restoran layanan cepat (QSRs) bahawa generasi milenial memiliki spesifikasi yang tepat dalam pesanan makanan mereka. Sementara makanan kombo telah muncul sebagai pilihan harga yang bernilai bagi generasi yang baru muncul ini, ada tren milenial yang berkembang dalam memesan makanan di luar penawaran kombo untuk konsumsi makanan pilihan mereka, sehingga mewujudkan pilihan makanan. Pertumbuhan ini juga didorong oleh pembatasan diet dan kepekaan yang terkait dengan kalangan milenial.

\section{Pilihan Makanan Generasi Milenial}

Generasi milenial tidak dapat dianggap sebagai kelompok yang homogen mengingat keperluan makanan dan pilihan peribadi mereka terus terfragmentasi. Perkembangan prospektif tersebut menggarisbawahi perlunya produsen makanan untuk lebih telus dalam pendekatan mereka seiring dengan banyaknya pilihan makanan khas milenial. Pilihan makanan diertikan sebagai pemilihan makanan untuk diambil, yang dihasilkan dari pengaruh berbagai faktor yang bersaing, memperkuat dan berinteraksi. Ini berkisar dari respons sensorik, fisiologi, dan respons psikologi individu konsumen hingga interaksi antara pengaruh sosial, lingkungan, dan ekonomi, dan mencakup beragam makanan yang tersedia dan kegiatan industri makanan dalam mempromosikan produk makanan mereka. Pilihan makanan (food choice) mengacu pada bagaimana orang memutuskan apa yang harus dibeli dan dimakan. Seperangkat faktor kompleks yang bervariasi dari orang ke orang dan tergantung pada budaya, warisan dan peningkatan semua pilihan makanan mempengaruhi. Kita mungkin mencari harga jika kita harus tetap pada anggaran, atau mencari informasi alergi jika kita memiliki alergi makanan. Tetapi pilihan makanan juga dapat dipengaruhi oleh karakteristik lain yang sesuai dengan pilihan peribadi (misalnya, label keberlanjutan untuk perdagangan yang adil, label organik atau informasi terkait kesihatan seperti tuntutan kesihatan). Faktor peribadi lebih lanjut yang mempengaruhi pilihan makanan dapat berupa kebiasaan atau rasa. Contoh jika seseorang mengucapkan "saya selalu membeli ini" maka kita dapat mengetahui bahawa yang bersangkutan selalu memilih makanan berdasarkan kebiasaan. Hal lain juga dapat bergantung pada suasana hati kita dan faktor-faktor lain seperti nafsu makan atau kerana terburu-buru.

Banyak faktor yang menentukan seseorang dalam memilih makanan. Furst et al. (1996) mengembangkan model konseptual mengenai pilihan makanan yang memberikan sumbangan untuk memahami praktik memilih makanan dan interaksi antara tindakan individu dalam memilih makanan dengan sistem makanan secara luas. Model tersebut juga mempunyai implikasi kepada teori mengenai pilihan makanan juga kepada kebijakan dan intervensi untuk perubahan pilihan makanan yang mempengaruhi kesihatan dan lingkungan. Menurut Steptoe et al. (1995) dengan menggunakan Food Choice Questionnaire (FCQ) maka para peneliti telah mengungkapkan beberapa faktor seperti kesehatan, harga, kenyamanan, suasana hati, daya tarik indera, kandungan bahan alamiah, kontrol berat badan, keakraban dan kekhuatiran turut mempengaruhi pilihan kita terhadap makanan. Menurut Grunert (2002), pilihan makanan dibingkai dalam hal harapan kita terhadap kualiti sebelum dan sesudah pembelian produk makanan. Penelitian juga telah menunjukkan hal yang berbeza dimana harga dan daya tarik indera adalah salah satu faktor terpenting yang mempengaruhi pilihan makanan (Costell et al., 2010; Steptoe et al., 1995). Dalam pembanding sensorik FCQ mencakup apakah makanan berbau harum, terlihat bagus, memiliki tekstur yang menyenangkan dan rasanya enak (Steptoe et al., 1995). Yang menarik adalah tidak hanya pilihan sensorik atau makanan kita memandu pilihan makanan, tetapi berbagai macam faktor lain juga berkontribusi pada pilihan makanan kita. 
Pendorong utama untuk makan tentu saja lapar tetapi apa yang kita pilih untuk dimakan tidak ditentukan semata-mata oleh keperluan fisiologis atau faktor nutrisi. Menurut Costell et al. (2010), respons konsumen terhadap produk makanan ditentukan oleh empat berbeda komponen. Pertama, konsumen merasakan karakteristik sensorik suatu produk. Kedua, konsumen memiliki respons umum terhadap suatu produk, yang merupakan komponen afektif. Ketiga, konsumen menerapkan kognitif komponen yang terkait dengan informasi yang dimiliki konsumen tentang produk dan sikap konsumen dan keyakinan. Keempat, respons dipengaruhi oleh komponen perilaku yang melibatkan niat atau orang tersebut tindakan untuk perilaku masa depan (Costellet al., 2010). Berdasarkan hasil studi literatur dari berbagai disiplin dan hasil penelitian (Fahrudin, 2015) mengenai pilihan makanan dan keinginan sosial (fooad choice and social desirability) dikalangan mahasiswa pekerjaan sosial di Indonesia ternyata ada beberapa faktor yang yang mempengaruhi pilihan makanan termasuk:

i. Faktor penentu biologis seperti rasa lapar, nafsu makan, dan rasa

ii. Penentu ekonomi seperti biaya, pendapatan, ketersediaan

iii. Penentu fisik seperti akses, pendidikan, keterampilan (mis. Memasak) dan waktu

iv. Penentu sosial seperti budaya, keluarga, teman sebaya dan pola makan

v. Penentu psikologis seperti suasana hati, stres dan rasa bersalah

vi. Sikap, kepercayaan dan pengetahuan tentang makanan

Kompleksiti pilihan makanan terlihat jelas dari faktor di atas, yang jika sendirian menjadi tidak lengkap. Faktor pilihan makanan juga bervariasi sesuai dengan tahap kehidupan, dan kekuatan satu faktor akan bervariasi dari individu ke individu lainnya atau dari satu kelompok orang ke kelompok yang berikutnya (Fahrudin et al, 2020). Dengan demikian, penting untuk diingat bahawa satu jenis intervensi sosial untuk mengubah perilaku pilihan makanan tidak akan cocok untuk semua kelompok populasi. Sebaliknya, intervensi perlu diarahkan pada kelompok populasi yang berbeza dengan mempertimbangkan banyak faktor yang mempengaruhi keputusan mereka tentang pilihan makanan. Tren makanan di kalangan milenial didorong oleh hasrat akan produk premium. Media sosial telah memainkan peran kunci dalam menarik milenium dengan semangat evangelis untuk mencuba atau mengkonsumsi makanan dari seluruh dunia, sehingga berdampak pada tren yang berlaku di industri makanan. Milenial telah muncul sebagai pemberi pengaruh utama sehubungan dengan gelombang revolusioner produk makanan baru yang dipamerkan di rak-rak ritel. Dari berbagai literatur bahawa berbagai faktor mempengaruhi industri makanan. Faktor-faktor tersebut tidak hanya terkait dengan pola konsumsi kaum milenial, tetapi juga pola pembelian dan perilaku makan mereka. Dalam hal ini, tren umum di kalangan milenial adalah penurunan belanja bahan makanan yang cukup besar menyusul kenaikan belanja makanan di luar rumah.

\section{Kesimpulan}

Dalam masyarakat moden saat ini dimana disrupsi terjadi dalam berbagai bidang maka pilihan makanan dalam kalangan anggota masyarakat juga telah mengalami perubahan. Orang lebih nyaman minum kopi di Starbuck Cafe atau Cafe daripada kopi tubruk di rumah atau di warung. Orang juga dengan segera dapat menikmati makanan apa saja yang diinginkan menggunakan aplikasi teknologi. Realitinya, bagaimana, mengapa, dengan siapa kita makan akan mempengaruhi apa yang kita makan. Keputusan untuk memilih dan memakan makanan tertentu jauh lebih kompleks karena melibatkan banyak faktor di antaranya faktor fisiologi, faktor psikologi, faktor sosial dan budaya, faktor ekonomi serta sikap dan pengetahuan mengenai makanan. Generasi milenial sangat memperhatikan pengambilan nutrisi dan selera mereka. Generasi konsumen ini memberi indikasi bahawa pembelian dan konsumsi produk pangan yang lebih sadar. Pengamatan penting dalam hal ini adalah meningkatnya kesediaan kaum milenial untuk membayar produk makanan yang melambangkan ketulusan dan keaslian. Intinya, tren makanan di kalangan milenial lebih didorong oleh keperluan emosional daripada materi. 


\section{Rujukan}

Bell, A. C., Stewart, A. M., Radford, A. J. \& Cairney, P. T. (1981) A method for describing food beliefs which may predict personal food choice. Journal of Nutrition Education, 13, 22-6.

Capon, N. (2016). Managing marketing in the 21st century: Developing and implementing the market strategy. Wessex Press.

Costell, E., Tárrega, A., \& Bayarri, S. (2010). Food Acceptance: The Role of Consumer Perception and Attitudes. Chemosensory Perception, 3(1), 42-50.

Fahrudin, A. (2015). Food choice and social desirability among social work students. Research Report. Jakarta: University of Muhammadiyah Jakarta.

Fahrudin, A., Fahrudin, F.I., Fahrudin, F.A. Yusuf, H. (2020). Konsep dan faktor penentu pilihan makanan. Dalam Fahrudin, A, Mohd Dahlan HA Malek, Suryanto \& Nurhidayah, Inovasi bisnis dan sosial di era disruptif. Yogyakarta: IDEA Press

Furst, F., Connors, M., Bisogni, C.A., Sobal, J. \& Falk, L.W. (1996). Food Choice: A Conceptual Model of the Process. Appetite, 26, 247-266

Honnappa, D. (2019). Food trends among millennials: Remodelling the food industry. Grand View Research https://knowledge.ulprospector.com/9440/fb-food-trends-among-millennialsremodeling-the-food-industry/ diakses 31 Agustus 2021

Inglehart, R., \& Carballo, M. (1997). Does Latin America Exist? (And is There a Confucian Culture?): A Global Analysis of Cross-Cultural Differences 1. PS: Political Science \& Politics, 30(1), 34-47.

Gillian, C. \& Wilson, M.S.R. (2009). Strategic marketing management. UK:Routledge.

Grunert, K.G. (2002). Current issues in the understanding of consumer food choice. Trends in Food Science \& Technology.13, 275-285

Lancaster, L. C., \& Stillman, D. (2003). When generations collide: Who they are, why they clash, how to solve the generational puzzle at work. New York, NY: Harper Business.

Leslie, John. (2016). The sugar conspiracy. The Guardian. http://www.theguardian.com/society/2016/apr/07/the-sugar-conspiracy-robert-lustig-john- yudkin April 7, 2016

Lewin, K. (1943) Forces behind food habits and methods of change. In The problem of changing food habits. Washington: National Academy of Sciences, Bulletin 108.

Lewin, K. (1951) (D. Cartwright, Ed.), Field theory in social science: selected theoretical papers. Pp. 170-87. New York: Harper Torch books.

Mela, D. (1999) Food choice and intake: the human factor. Proceedings of the Nutrition Society, 58, 513-521

Michela, J. \& Contento, I. (1986) Cognitive, motivational, social, and environmental factors on food choices. Health Psychology, 5, 209-30.

Steptoe A, Pollard T \& Wardle J (1995) Development of a measure of the motives underlying the selection of food: the food choice questionnaire. Appetite 25, 267-284.

Watson, Elaine. (2016). What millennials want: From customization to continuous snacking. Prepared Foods. http://www.foodnavigator-usa.com/ Trends/Trendspotter/Packaged-factsexploresMillennial-food-trends

Wohl, Jessica. (2016). Pepperidge Farm Puffs up Pastry Sales with Help from Videos. GMA SmartBrief. http://adage.com/article/cmo-strategy/ pepperidge-farm-puffs-pastry-sales-online video/303803/ 62 